\title{
BLACK BANGLE (ZINGIBER OTTENSII VAL.) RHIZOME AND KATUK LEAVES (SAUROPUS ANDROGYNUS L. MERR) EXTRACT COMBINATION PROTECTIVE ROLE ON ADIPOSE TISSUES HISTOLOGIC PROFILE OF HIGH-FAT AND CARBOHYDRATE DIET-INDUCED OBESE MALE RATS
}

\author{
AGUS SULAEMAN, PATONAH, GHINA GRECIA NEGARA
}

Department of Pharmacology, Bandung School of Pharmacy, Jl. Soekarno Hatta No.754, Cipadung Kidul, Panyileukan, Bandung, Indonesia. Email: agus.sulaeman@stfb.ac.id

Received: 6 December 2017, Revised: 3 February 2018 and Accepted: 14 February 2018

ABSTRACT

Objective: The effect of Zingiber ottensii Val. rhizome and Sauropus androgynus L. Merr leaves extract combination was investigated using histologic profile of adipose tissues in obese male rats induced by high-fat and carbohydrate diets.

Methods: This was a preventive study, conducted for 42 days by simultaneous administration of diets and extracts administration. The subjects were divided into 8 groups. All groups except negative control group were fed with high-fat and carbohydrate diets. Orlistat, metformin, and curcumin were used as contrast.

Result: The phytochemical screening of Z. ottensii Val. rhizome extract showed the presence of flavonoids, saponins, and triterpenoids, meanwhile $S$. androgynus L. Merr leaves extract presented flavonoids, tannins, saponins, steroids, and triterpenoids. The results showed tissues histological differences in all test group compared with positive control. The most effective combination dose for bangle and katuk leaves extract in protecting adipose tissue was $100 \mathrm{mg} / \mathrm{Kg}: 100 \mathrm{mg} / \mathrm{Kg}$ body weight.

Conclusion: The combination of black bangle and katuk leaves extract showed a protective role, demonstrated by adipose tissues histologic profile.

Keywords: Zingiber ottensii Val., Sauropus androgynus (L.) Merr, Histology score, Adipose tissue.

(C) 2018 The Authors. Published by Innovare Academic Sciences Pvt Ltd. This is an open access article under the CC BY license (http://creativecommons. org/licenses/by/4. 0/) DOI: http://dx.doi.org/10.22159/ajpcr.2018.v11s1.26613

\section{INTRODUCTION}

Obesity is suggested to promote oxidative stress by increasing nicotinamide adenine dinucleotide phosphate oxidase and decreasing antioxidant enzymes, and together these conditions will induce local adipocytokines expression dysregulation. Lawrence et al. in his translating pendulum hypothesis (personal communication) explained about oxidative stress versus antioxidant homeostasis. Microenvironment disturbance could be happened in individuals with impairment glucose tolerance, shifting this homeostasis to a higher oxidative stress, and then facilitating the inflammation. Improving a healthier lifestyle, better workout, and maybe some therapy was thought to neutralize the homeostasis and shift the body back to the "non-inflammed" condition. Not only Iowa Gambling Task but also this phenomenon could happen in any individuals with metabolic impairment, such as obesity. Chronically, the homeostasis shifting between oxidative stress and antioxidant which also affect the inflammation-non-inflammation status in individuals will count not only quantitatively but also in some point will significantly alter the body homeostasis in quality level, escaping from Quantum Leap phenomenon, and cannot be explain mechanistically [1].

The pathogenesis of obesity was a long story, began with over intake of carbohydrate and fat. Overnutrition could promote energy imbalance, which will alter the inflammation-anti-inflammation homeostasis, as well as the blood lipid concentration. The impairments will result in adipose tissue histological profile alteration, altogether with weight gain will finally induce obesity. Obesity treatment usually performed in many ways such as caloric (diet) restriction, physical exercises, and/ or synthetic medications. Indonesia has about 25,000-30,000 species of plants which included $80 \%$ of worldwide plants' species and $90 \%$ of Asia's. Most of this abundance has potencies to be applied as industrial plants, fruity plants, herbals, and especially medicinal plants [2].

Black bangle rhizomes (Zingiber ottensii Val.) were used for sedativum, antioxidant, anti-inflammatory agent, and decrease obese [3]. Katuk leaves (Sauropus androgynus L. Merr) has been used widely in Indonesia. A study from the National Working Group of Indonesian Medicinal Plant described some active ingredients in katuk including papaverine alkaloid, protein, fat, some vitamins and minerals, saponins, flavonoids, and tannins, which some of them could be developed for phytomedicine [4]. The combination of bangle and katuk leaves was expected to perform synergic effects of therapy while reducing the unpleasant smell of bangle rhizome.

\section{METHODS}

This study has been ethically approved by Ethics Committee Health Research Faculty of Medicine Padjadjaran University Bandung No: 528 /UN6.C.10/PN/2017 with Reg No. 0217020126.

\section{Plant material preparation and determination}

Black bangle rhizomes ( $Z$. ottensii Val.) and katuk leaves ( $S$. androgynus L. Merr) were obtained from Manoko plantation in Lembang, Bandung. Plants determination were performed in Herbarium Laboratory, Department of Biology, Padjadjaran University (UNPAD).

\section{Preparation of crude extract}

Black bangle rhizomes (Z. ottensii Val.) and katuk leaves (S. androgynus L. Merr) were screened and extracted using maceration method with $96 \%$ ethanol in room temperature for $3 \times 24 \mathrm{~h}$. Extract was then filtered and concentrated using rotary evaporator at $50-60^{\circ} \mathrm{C}$.

\section{Phytochemical screening}

Obtained extract underwent for secondary metabolites examination: Alkaloid, flavonoid, quinone, saponin, tannin, and triterpenoid/ steroid [5].

\section{Animals}

White male rats age 2-3 months weighing between 200 and 300 g were divided into eight groups: 
- Group $1(\mathrm{C}-)$ : Negative control was fed with standard diet (normal).

- Group $2(\mathrm{C}+)$ : Positive control was fed with high-fat, high carbohydrate diet $+0.5 \% \mathrm{Na}-\mathrm{CMC}$ suspension.

- Group 3 (G3): Was fed with high-fat, high carbohydrate diet+orlistat $10.8 \mathrm{mg} / \mathrm{kg}$ body weight in $0.5 \% \mathrm{Na}-\mathrm{CMC}$ suspension.

- Group 4(G4): Was fed with high-fat, high carbohydrate diet+metformin $45 \mathrm{mg} / \mathrm{kg}$ body weight in $0.5 \% \mathrm{Na}-\mathrm{CMC}$ suspension.

- Group 5 (G5): Was fed with high-fat, high carbohydrate diet+curcumin $1.8 \mathrm{mg} / \mathrm{kg}$ body weight in $0.5 \% \mathrm{Na}-\mathrm{CMC}$ suspension.

- Group 6 (G6): Was fed with bangle and katuk leaves extract $100 \mathrm{mg} / \mathrm{kg}: 100 \mathrm{mg} / \mathrm{kg}$ body weight in $0.5 \% \mathrm{Na}-\mathrm{CMC}$ suspension.

- Group 7 (G7): Was fed with bangle and katuk leaves extract $100 \mathrm{mg} / \mathrm{kg}: 75 \mathrm{mg} / \mathrm{kg}$ body weight in $0.5 \% \mathrm{Na}-\mathrm{CMC}$ suspension.

- Group 8 (G7): Was fed with bangle and katuk leaves extract $100 \mathrm{mg} / \mathrm{kg}: 50 \mathrm{mg} / \mathrm{kg}$ body weight in $0.5 \% \mathrm{Na}-\mathrm{CMC}$ suspension.

This was a preventive study for 42 days or until the positive control reaches $\geq 20 \%$ from initial weight.

Inflammation markers measurement: Aspartate aminotransferase (AST) and alanine aminotransferase (ALT)

AST and ALT enzymes were quantified with enzymatic method, in Microlab 300 using Proline ALAT (GPT) FS (IFCC MOD) no batch 316494116537, and Proline ASAT (GOT) FS (IFCC MOD) no batch 316051400117024

Body weight and body fat measurement, as energy imbalance effect

Body weight was measured daily using calibrated scale. Body fat was measured by weighing perirenal fat, testical fat, and retroperitoneal fat. Rats were chosen randomly and sacrificed after.

Fat overflow measurement: Triglyceride

Triglyceride was quantified with Microlab 300 using Proline reagent batch ${ }^{\#} 3165341116569$.

\section{Adipose tissue histology}

Histology examination was performed in Indonesian Research Center for Veterinary Science in Bogor, Harris-hematoxylin eosin staining was performed, and adipose tissue histological structure was observed for any alienation, vacuolization, mineralization, epithelization, and lymphoid in adipose tissue.

\section{RESULTS}

\section{Preliminary phytochemical screening}

From black bangle (Z. otensii Val.) extract, flavonoid, saponin, and triterpenoid were identified, while from katuk leaves $(S$. androgunus L. extract, flavonoid, tannin, saponin, steroid, and triterpenoid were identified).

Black bangle rhizomes ( $Z$. ottensii Val.) and katuk leaves (S. androgynus L. Merr) effect in adipose tissue histological profile observation

Metabolism impairment parameters in this study were measured for the weight of fat in specified organs, liver enzymes, and triglyceride.

Fat weight measurement in specified organs was aimed to observe the body lipid distribution as shown in Tables 1 and 2 .

Perirenal fat weight and testical fat weight decreased significantly compare to $\mathrm{C}+$ in all groups except for $\mathrm{G} 3$, while in retroperitoneal fat weight, all groups decreased significantly except for G6. The most effective combination dose for bangle and katuk leaves extract in adipose tissue was $100 \mathrm{mg} / \mathrm{Kg}: 100 \mathrm{mg} / \mathrm{Kg}$ body weight.

Liver enzymes were measured in this study to observe the inflammation.

The results showed significant differences in AST and ALT level between C+ with G5 and G6. The most effective combination dose for bangle and katuk leaves extract in adipose tissue was $100 \mathrm{mg} / \mathrm{Kg}: 100 \mathrm{mg} / \mathrm{Kg}$ body weight.

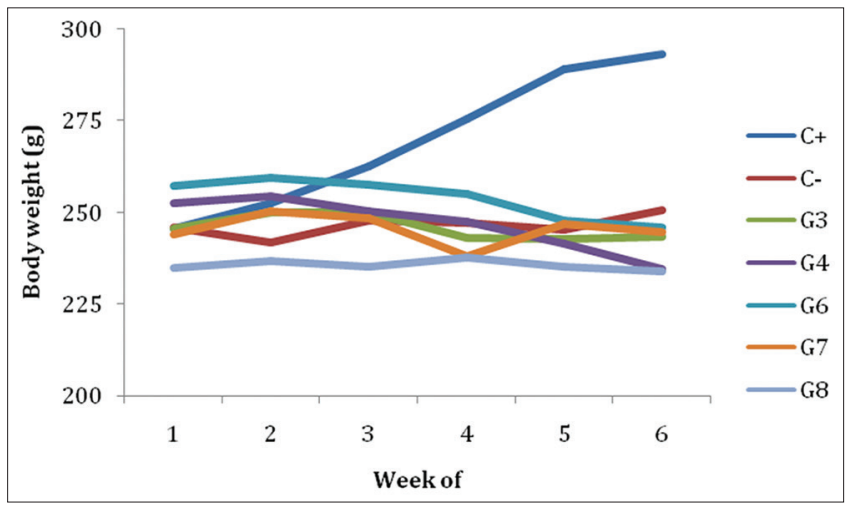

Fig. 1: Body weight (mg) means from week 1 until week 7 after high-fat and high carbohydrate diet

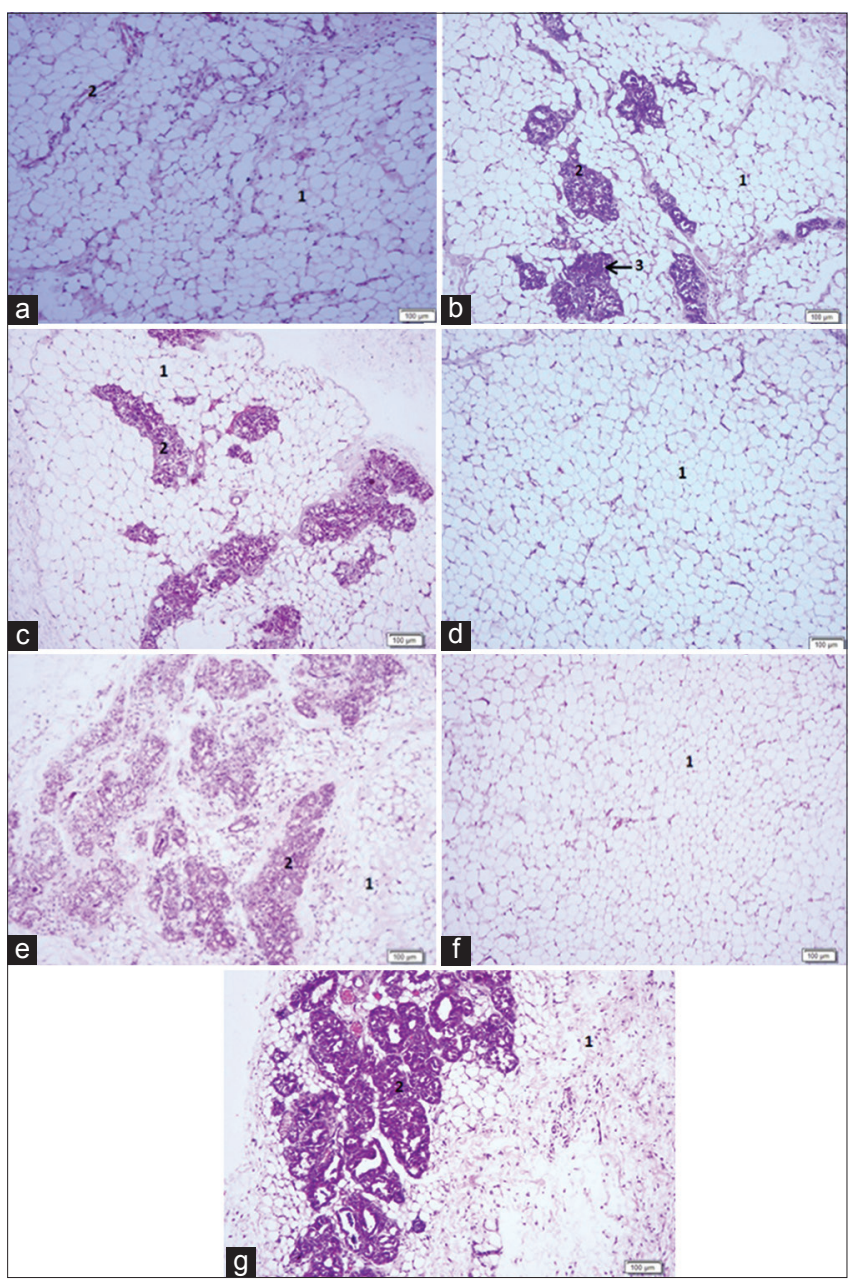

Fig. 2: (a) C+ rat no 3. Epithelialization and mineralization of adipose tissue; 1. Fat globules, 2. Epithelialization, and 3. Mineralization (H and E, $\times 100$ ). (b) C-rat no 5. No specific abnormality; 1. Fat globulus 2. Peripheral blood vessel (H and E, $\times 100$ ). (c) G3 rat no 1. Epithelialization of adipose tissue; 1 . Fat globulus, 2. Epithelialization (H and E, $\times 100$ ). (d) no 5G4 rat. No specific abnormality; 1 . Fat globulus $(H$ and $E, \times 100)$.

(e) G6 rat no 4. Epithelialization of adipose tissue; 1. Fat globulus, 2. Epithelialization (H and E, ×100). (f) G7 rat no 3 . No specific abnormality; 1. Fat globulus ( $H$ and $E, \times 100)$. (g) G8 rat no 3. Epithelialization of adipose tissue; 1 . Fat globulus, 2. Epithelialization $(\mathrm{H}$ and $\mathrm{E}, \times \mathbf{1 0 0})$ 
Table 1: Fat weight means (mg) in specified organs

\begin{tabular}{llllll}
\hline Organ & C+ & C- & G3 & G6 & G8 \\
\hline Perirenal fat & $1.59 \pm 0.17$ & $0.31 \pm 002^{*}$ & $1.80 \pm 0.16$ & $1.06 \pm 0.23^{*}$ & $0.77 \pm 0.21^{*}$ \\
Testical fat & $3.30 \pm 0.27$ & $0.44 \pm 0.07^{*}$ & $2.09 \pm 0.19$ & $0.79 \pm 1.12^{*}$ & $1.54 \pm 0.16^{*}$ \\
Retroperitoneal fat & $2.60 \pm 0.17$ & $0.55 \pm 0.48^{*}$ & $1.62 \pm 0.10^{*}$ & $0.99 \pm 0.34^{*}$ & $2.73 \pm 1.40$ \\
\hline
\end{tabular}

*Significant differences to $\mathrm{C}+$

Table 2: AST (IU/L) and ALT (IU/L) level means

\begin{tabular}{lll}
\hline Group & $\begin{array}{l}\text { Mean level of AST } \\
\text { (IU/L) } \pm \text { SD }\end{array}$ & $\begin{array}{l}\text { Mean level of ALT } \\
\text { (IU/L) } \pm \text { SD }\end{array}$ \\
\hline C+ & $138.07 \pm 15.11^{\#}$ & $67.03 \pm 2.67$ \\
C- & $119.77 \pm 15.48^{* \#}$ & $77.66 \pm 3.69$ \\
G5 & $114.57 \pm 5.93^{*}$ & $64.06 \pm 4.83^{*}$ \\
G6 & $87.30 \pm 32.91^{*}$ & $48.43 \pm 0.35^{*}$ \\
G7 & $111.83 \pm 44.56^{*}$ & $65.36 \pm 12.99^{*}$ \\
G8 & $101.63 \pm 10.70^{*}$ & $69.96 \pm 3.21$ \\
\hline
\end{tabular}

*Significant differences to C+. AST: Aspartate aminotransferase, IU:

International units, ALT: Alanine aminotransferase, SD: Standard deviations

Table 3: Triglyceride level (mg/dl) means

\begin{tabular}{ll}
\hline Group & Mean of triglyceride level T42 $(\mathbf{m g} / \mathbf{d l}) \pm$ SD \\
\hline C+ & $145.90 \pm 29.95$ \\
C- & $81.43 \pm 6.25$ \\
G3 & $67.83 \pm 20.54^{*}$ \\
G6 & $85.66 \pm 10.27$ \\
G7 & $87.16 \pm 11.41$ \\
G8 & $100.71 \pm 76.61$ \\
\hline *Significant differences to C+. SD: Standard deviations
\end{tabular}

Table 4: Adipose tissue improvement score results

\begin{tabular}{ll}
\hline Group & Mean of histological scoring adipose tissue $(\mathrm{x} \pm \mathrm{SD})$ \\
\hline C+ & $\mathbf{1 0 . 0 0 \pm 4 . 8}$ \\
C- & $\mathbf{3 . 3 3} \pm \mathbf{2 . 5 1}$ \\
G3 & $\mathbf{2 . 3 3} \pm \mathbf{1 . 1 5}$ \\
G4 & $\mathbf{1 . 6 6} \pm \mathbf{1 . 1 5}$ \\
G6 & $2.33 \pm 1.15$ \\
G7 & $1.66 \pm 1.15$ \\
G8 & $2.33 \pm 1.15$ \\
\hline
\end{tabular}

*Significant differences to C+. SD: Standard deviations

Table 3 shows significant differences between $\mathrm{C}-$, $\mathrm{C}+$, and other groups. The most effective combination dose for bangle and katuk leaves extract in adipose tissue was $100 \mathrm{mg} / \mathrm{Kg}: 100 \mathrm{mg} / \mathrm{Kg}$ body weight.

\section{Body weight and adipose tissue histology}

High-fat and high carbohydrate dietary change will induce obesity showed by increased body weight and altered adipose tissue histology. Body weight changes could be seen in Fig. 1.

Adipose tissue histology was observed to identify any damage in adipose tissue such as vacuolization, mineralization, epithelialization, and hyalinization. The histological results could be found in Fig. 2a-g. The scoring of these histological results can be found in Table 4 .

The scores in all groups were significantly lower compared to $\mathrm{C}+$. The most effective combination dose for bangle and katuk leaves extract in adipose tissue found was $100 \mathrm{mg} / \mathrm{Kg}: 75 \mathrm{mg} / \mathrm{Kg}$ body weight.

\section{DISCUSSION}

Due to phytochemical screening, black bangle rhizomes contain flavonoid, saponin, and triterpenoid. The result were different with study performed by Hasimun et al. which found flavonoid, tannin, and triterpenoid from the same rhizomes [6]. Our results on katuk leaves did not find alkaloid, compared to the finding in ethanol extract performed in a study by Susanti et al. [7]. The differences could be affected by the differences of plantation location and environment. Plantation location was known to significantly affect the substances contained in plants. Viyada (2016) showed that Zingiber ottensii has curcuminoid content and terpinen-4-ol in the essential oil [8]. Iwansyah et al. showed that the ethanolic extract of SA with a ratio of total flavonoids to total phenolics (TF/TP) was 1.59 contained the highest average of total flavonoids than Moringa oleifera, Carica papaya and Plectranthus amboinicus L. [9]. Marliani et al. showed that the essential oil of Zingiber ottensii Val. leaves contains 37 components with main component respectively as trans-caryophyllene, $\beta$-elemene, zerumbone, 1,5-cyclodecadiene, (-)-caryophyllene while essential oil of rhizome contains 64 components with main component respectively as 1-4-terpineol, zerumbone, sabinene, 1,8-cineole, and -terpinene [10].

Our study showed that metabolism impairment could promote the metabolism remnant lipid accumulation in perirenal, testical, and retroperitoneal. Bangle rhizomes' and katuk leaves' extract were suggested to prevent lipid accumulation in the three organs. Both active substances might play roles in increasing lipid metabolism, thus preventing the tissues lipid accumulation [11].

The same dose combination also showed to prevent AST and ALT enzymes increased. Curcumin was used as contrast due to the previous studies which demonstrated a decreasing in abdominal fat by essential oil from curcuma extract through beta-oxidation regulation in liver peroxisome. Curcumin and the essential oil synergistically regulate lipid metabolism ruler genes. One study showed that Temulawak (Curcuma xanthorriza Roxb.) performs anti-inflammatory, antibacterial, and hepatoprotective effects. Temulawak contains curcuminoid, essential oil, and starch [12]. The essential oil can be used as inducing agent for apoptosis, anti-inflammatory, antibacterial, and antioxidant. Meanwhile, curcumin performed a hepatoprotective activity and can prevent liver diseases [7]. A study by Kim demonstrated a positive correlation between ALT and metabolic syndrome even in normal scale [13]

Bangle rhizome and katuk leaves' extract was found to prevent the triglycerides serum level increasing. This could be due to the antioxidant property from flavonoid contained in the extract $[8,10]$, which neutralizes the free radical produced by high-fat and high carbohydrate diet, and then preventing the insulin resistance. Our study showed a significant increase in body weight between $\mathrm{C}-$ and $\mathrm{C}+$ with all groups, suggested that the extract combination could prevent the weight gain in rats with high-fat and high carbohydrate diet.

In the histological examination, $\mathrm{C}+$ tissues demonstrated destructed adipose tissue. C- tissues demonstrated no specific destruction, in other words, normal. G3 and G4 tissues demonstrated almost the same description with $\mathrm{C}$-.

Mir SA et al. showed that polyphenols may inhibit pre-adipocyte to adipocyte differentiation, cause adipocyte apoptosis, decrease fat absorption from gut, uptake of glucose by skeletal muscles, suppress lipid biosynthesis and promote catabolism in adipose, liver and other tissues [13]. They may promote anti-inflammatory molecules in adipose tissue. Adipocytes generate reactive oxygen species due to fatty acid oxidation in mitochondria and peroxisomes that may lead to oxidative stress under obesity [13].

This suggests that the extract combination can be used to prevent the adipose tissue alteration with dosage $100 \mathrm{mg} / \mathrm{Kg}: 100 \mathrm{mg} / \mathrm{Kg}$ body weight.

\section{CONCLUSION}

The combination of black bangle and katuk leaves extract showed a protective role, demonstrated by adipose tissues histologic profile. 


\section{REFERENCES}

1. Lawrence $\mathrm{J}$, et al. The Interaction of free Fatty Acid, Total Antioxidant Status, Plasminogen Activator Inhibitor-1, Adiponectin and high sensitivity C-Reactive Protein on the Occurrence of Impaired Glucose Tolerance, Dissertation, Hasanuddin University Makassar; 2005.

2. Dewoto HR, Hedi R. Development of Indonesian traditional medicine to phytofarmaka. Indones Med Mag 2007;57:205-211.

3. Wijayakusuma HM, Dalimarta S, Wirian AS. Medicinal Plant from Indonesia. Jakarta: Kartini Library Publisher; 1997.

4. Rukmana R, Indra MH. Katuk Leaves. The potencial and Benefit. Yogyakarta: Kanisius; 2003.

5. Ministry of Health Republic of Indonesia. Indonesian Medical Material. Vol. VI. Jakarta: Ministry of Health Republic of Indonesia; 1996.

6. Hasimun P, Adnyana IK, Valentina R, Lisnasari E. Potential alphaglucosidase inhibitor from selected zingiberaceae family. Asian J Pharm Clin Res 2016;9:164-7.

7. Susanti NM, Budiman IN, Warditiani NK. Phytochemical screening ethanol extract of katuk leaves (Sauropus androgynus (L.) Merr.). Journal of Faculty of Mathematical and Life Science. Vol. 2. Surakarta: Udayana University; 2014

8. Kantayos V, Paisooksantivatana Y. Antioxidant activity and selected chemical components of 10 zingiber spp in Thailand. J Dev Sus Agr
2012,7:89-96

9. Iwansyah, Ade, Rizal M, Damanik, Kustiyah L, Hanafi M. Relationship between antioxidant properties and nutritional composition of some galactopoietics herbs used in indoneisa: A comparative study. Int $\mathbf{J}$ of Pharm and Pharmaceutical Sciences 2016:236-243.

10. Marliani L et al. Essential Oil Components of Leaves and Rhizome of Zingiber ottensii Val. from Bandung, Indonesia, Res J Chem Environ 2018;22:(Special Issue I).

11. Warditiani, Kadek N, Milawati, Pitri Susanti NM. Antidyslipidemic activity of katuk leaves saponins fraction (Saoropus androgynous (L) Merr In Rats Induced With Fat-Rich Diet. Int $\mathrm{J}$ of Pharm and Pharmaceutical Sci 2016;418-420.

12. Utami A, Meryalita R, Prihatin NA, Ambarsari L, Kurniatin PA, Nurcholis W, et al. DNA Methods Variation of Temulawak Leaves (Curcuma xhanthorriza. Roxb). Indonesian: Proceeding of UNESA National Seminar of Chemistry; 2012.

13. Kim C. Severity of ultrasonographic liver steatosis and metabolic syndrome in Korean men and women. World J Gastroentrol 2005;11:5314-21.

14. Mir SA, et al. Understanding the role of active components from plant sources in obesity management. Journal of the Saudi Society of Agricultural Sciences 2017. Available From: http://dx.doi. org/10.1016/j.jssas.2017.04.003. 